\title{
REPRESENTASI PEMASARAN MELALUI MAJALAH MINI MENGGUNAKAN MEDIA SOSIAL INSTAGRAM
}

\author{
Muhamad Yusup ${ }^{1}$, Nurlaila Suci Rahayu Rais ${ }^{2}$, Yunita Kartika Sari ${ }^{3}$ \\ ${ }^{1,2,3}$ STMIK Raharja Tangerang, Jl. Jendral Sudirman No. 40 Modern Cikokol -Tangerang \\ E-mail: - yusup@ raharja.info, ${ }^{2}$ nurlaila@ raharja.info, ${ }^{3}$ yunita.kartika@ raharja.info
}

\begin{abstract}
ABSTRAKSI
Penulisan artikel ini dibuat kepada masyarakat modern yang menginginkan program memasarkan produk yang lebih mudah, efisien, efektif dan praktis, dalam mencari suatu informasi dan memperoleh sebuah produk, masyarakat umumnya memaksimalkan alat komunikasi yang dilengkapi internet, dengan kemajuan perangkat komunikasi yang dilengkapi fasilitas internet, masyarakat dimanjakan oleh bentuk-bentuk aplikasi yang didukung melalui internet, melalui kemajuan teknologi media instagram maka disediakanfasilitas berupa tampilan visualisasi yang menarik, mudah diingat dan mudah digunakan.Metode yang di gunakan sangat sederhana, hanya dengan menggunakan perangkat elektronik seperti komputer PC, smartphone, maupun tablet yang biasa di gunakan seharihari oleh masyarakat modern, karena perangkat tersebut mudahdiaksesnya dengan tampilanvisualisasi fiturfitur yang disediakan.Melalui media instagram, masyarakat dimudahkan dalam menawarkan produk menemukan jenis produk, mendapatkan referensi gaya busana, jenis makanan, lokasi lokasi pariwisata yang harus dikunjungi, bentukbentuk informasi yang aktual dan faktual dapat ditemukan.
\end{abstract}

Kata Kunci-Pemasaran, Majalah, Instagram.

\begin{abstract}
Writing this article made to modern society who want program market products easier, efficient, effective and practical, in search for a information and obtained a products, the community generally maximize a means of communication equipped the internet, with the progress communications device equipped internet facilities, the community spoiled by forms application supported under the internet, through technological progress media instagram so provided facilities in the form of display visualizations interesting, easy to remember and easy to use.The method in use very simple, using just electronic devices such as pc computer, smartphone, and tablet ordinary use a day in day by modern society, because the device easy access it with visualization display features a feature provided.Through the instagram, held in public offering find the kind of product products, get reference style fashion, kinds of food, locations to visited tourism, forms of information actual and factual can be found.
\end{abstract}

Keywords—Marketing, Magazine, Instagram.

\section{PENDAHULUAN}

Saat ini penggunaan alat komunikasi sudah semakin berkembang dan meningkat seiring perkembangan teknologi, perangkat komunikasi atau yang sering kita sebut sebagai smartphone pun bermacam macam Sistem Operasinya (OS), sebut saja seperti android, iOS, windows, dan lain sebagainya. Penggunaan smartphone pun tidak terlepas dari yang namanya internet, internet dapat di akses jika kitamenyalakan data seluler atau wifi. Saat ini internet dapat di gunakan untuk beragam hal, seperti berkomunikasi, menonton video atau acara televisi, bertukar data, atau juga mencari dan memberikan informasi.

Dan yang saat ini sedang banyak di lakukan masyarakat adlah memanfaatkannya untuk memberikan informasi mengenai produk yang dijualnya, maupun mencari tau produk yang ingin di beli. Dalam hal menjual produk, untuk memasarkan dan memberikan informasinya tidaklah sesulit 
dahulu dengan cara menyebarkan brosur, pamflet, atau memasang banner dan baliho. Sekarang dalam memasarkan dan memberi informasi sebuah produk dapat di topang oleh internet, caranya pun mudah, hanya dengan memasukkan gambar dan informasi lengkap tentang sebuah produk.Karena menurut survei yang di lakukan oleh Asosiasi Penyelenggara Jaringan Internet Indonesia (APJII) pada tahun 2016, penguna internet di Indonesia mencapai 132,7 juta orang, dari jumlah penduduk Indonesia yang mencapai 256,2 juta.

Itu artinya saat ini internet adalah tempat yang memiliki peluang besar untuk di gunakan sebagai media pemasaran dan penyebaran informasi. Dan media di internet yang saat ini dengan banyak di pakai adalah sosial media Instagram. Namun dalam memasarkan dan memberi informasi dari sebuah produk melalui dunia maya khususnya media sosial Instagram, memiliki beberapa kendala seperti keterbatasan dalam mengakses informasi karena informasi tersebut hanya dapat di akses melalui pc, tablet, atau smartphone.Dan karena media ini berbasis internet,untuk mengaksesnya membutuhkan biaya seperti menggunakan paket data internet atau juga dapat menggunakan wifi, dan informasinya hanya dapat di akses melalui aplikasi Instagram, atau melalui website instagram.Dankarena baru setengah dari seluruh penduduk Indonesia bisa mengakses internet, itu berarti masih ada sebagian penduduk Indonesia yang belum melek teknologi, dan masih belum mengerti cara mengakses internet di karenakan faktor umur yang sudah tua sehingga susah memahami hal baru, keterbatasan biaya hidup, atau karena daerah tempat tinggal mereka yang belum terjangkau oleh jaringan yang di gunakan untuk mengakses internet.

Tetapi karena banyaknya pengguna Instagram yang terus meningkat, pada tahun 2016 pengguna Instagram di seluruh dunia mencapai 600 juta, sedangkan pengguna Instagram di Indonesia mencapai 22 juta. Itu artinya peluang untuk memasarkan dan memberi informasi suatu produk di Instagram sangat besar. Dan dengan tampilan baru dimana orang bisa melihat informasi terkini dan produk produk terbaru sehingga menarik minat masyarakat untuk melihat lihat.Dengan banyaknya akun online shop yang merajalela di instagram, dan banyaknya akun mengenai tren gaya hidup terkini, penelitian ini hadir untuk mengkombinasikan keduanya, yaitu memadukan informasi dalam memasarkan produk dan informasi mengenai tren gaya hidup masa kini yang akan di kemas menjadi lebih menarik dengan desain tampilan ala tren modern 2017. Dengan memanfaatkan fitur slide di Instagram, sehingga konten yang di letakkan di instagram nantinya dapat dimasukkan hingga maksimal 10 gambar tiap 1 kali unggahan, dengan ukuran 1:1, sehingga nantinya menyerupai seperti sebuah majalah berbentuk mini yang di letakkan di media sosial Instagram, itu lah yang kami manfaatkan dan kami beri nama majalah mini. Dengan adanya majalah mini ini akan semakin mempermudah dan merubah gaya hidup masyarakat menjadi lebih praktis tanpa perlu membeli majalah atau koran cetak dan tidak perlu mencari setiap informasi dari tiap satu produk, lebih menghemat biaya, sehingga nantinya pola hidup menjadi lebih di permudah hingga meningkatkan taraf hidup masyarakat.

\section{KAJIAN PUSTAKA}

Definisi Promosi

Promosi adalah kegiatan memberitahukan produk atau jasa yang hendak ditawarkan kepada calon konsumen atau wisatawan yang dijadikan target pasar. [1]

Promosi adalah tindakan menginformasikan atau meningkatkan konsumen tentang spesifikasi produk atau merek. Promosi mempunyai kekuatan untuk menyampaikan pesan, dan diperlukan perancangan khusus agar promosi tersebut memiliki visual yang kuat dan menciptakan keserasian di dalam rangkaian pemasaran, karena promosi adalah berkaitan langsung dalam upaya untuk memperkenalkan produk kepada konsumen dengan memikat hati mereka melalui pemberian kesan-kesan baik, yang mampu diingat dan dirasakan oleh konsumen.[2]

Definisi Majalah

Majalah ialah publikasi atau terbitan secara berkala yang memuat artikel-artikel dari berbagai penulis.[3] 


\section{METODE PENELITIAN}

Di dalam penelitian ini di terapkan beberapa metode yaitu :

1. Metode Analisa Permasalahan, di dalam metode ini di tentukan topik permasalahan penelitian, yakni melakukan interview kepada para pelaku UKM (Usaha Kecil Menengah) seperti beberapa orang yang masih berstatus sebagai pelajar maupun pekerja tetapi memiliki usaha sampingan kecil - kecilan.

2. Metode Pengumpulan Data yaitu dengan cara melakukan wawancara kepada para pelaku UKM (Usaha Kecil Menengah) tersebut, dan mendatangi lokasi UKM (Usaha Kecil Menengah) mereka untuk mengumpulkan data.

3. Analisa Data yakni mengolah dan memilih yang telah di kumpulkan berdasarkan hasil wawancara dan dari data yang telah di dapat.

4. Metode Analisa Perancangan, ialah memproduksi menggunakan software atau aplikasi program untuk merancang design design dari majalah yangdi buat.

5. Konsep design yaitu berisi tentang perencanaan media, tujuan media, dan strategi pesan.

\section{LITERATURE REVIEW}

1. Penelitian yang dilakukan oleh Sudarmaji pada tahun 2015, penelitian ini berjudul "RANCANG BANGUN MAJALAH KAMPUS ONLINE BERBASIS WEB”. Penelitian menjelaskan tentang Kemajuan ilmu pengetahuan dan teknologi yang begitu cepat sangat mempengaruhi Perkembangan pemrograman web saat ini. Salah satunya mendesain web dengan menggunakan macromedia 8 adalah script pemrograman yang mengatur bagaimana kita menyajikan informasi di dunia internet dan bagaimana informasi itu membawa kita melompat dari satu tempat ke tempat lainnnya. Penulis memilih objek penelitian di Politeknik Indonusa Surakarta yang merupakan perguruan tinggi yang berbasis pada teknologi informasi. di Surakarta. Berdasarkan penelusuran yang dilakukan penulis, Majalah kampus belum dapat diakses secara luas oleh mahasiswa/masyarakat luar. Di mana info-info penting tentang kampus terlambat atau tidak sama sekali diketahui oleh mahasiswa karena kurangnya daya akses dari majalah kampus itu sendiri. Sehingga banyak kegiatan maupun event yang ada di kampus kharisma tidak diikuti oleh mahasiswa maupun alumni. Hal ini dianggap kurang efisien sehingga dibutuhkan sebuah sistem, agar majalah kampus dapat diakses secara luas melalui jaringan internet dengan tampilan yang menarik yang cepat dan efisien. Penelitian ini mengembangkan suatu sistem informasi yang dapat memudahkan mahasiswa maupun dosen dalam mencari informasi kegiata-kegiatan yang berlangsung pada kampus Politeknik Indonusa Surakarta. Penulis merancang sistem informasi ini dan mengimplementasikan hasil rancangan kedalam bahasa pemograman web dengan macomedia 8 sebagai pengolahan basis data. Hasil dari uji coba yang dilakukan adalah sistem yang dirancang telah berjalan sesuai dengan rancangan penulis, yaitu membuat web majalah online yang memberikan informasi kegiatan - kegiatan yang berlangsung pada ruang lingkup.[4]

2. Penelitian yang dilakukan oleh Firmansyah Yudarnadi dan Nicko Willy Santoso, pada tahun 2015, penelitian ini yang berjudul "PEMBUATAN MAJALAH DIGITAL MAGAZINE SEBAGAI MEDIA PROMOSI WISATA DAN BUDAYA KARESIDENAN MADIUN DENGAN MENGGUNAKAN SOFTWARE PENGOLAH GRAFIS". Penelitian ini mejelaskan tentang "MADIUN MAGZ" merupakan majalah digital yang dibuat dan didedikasikan untuk masyarakat Madiun. Tujuan dari dibuatnya majalah digital ini yaitu sebagai media komunikasi serta sarana informasi untuk memberikan informasi kepada masyarakat khususnya masyarakat madiun untuk mengetahui wisata serta potensi alam apa saja yang ada di karesidenan Madiun ini. Dari hal di atas penulis ingin memberiakan suatu ide agar para pembaca lebih mudah untuk membaca majalah yaitu dengan membuat suatu majalah digital yang dimana para pembaca tidak repot serta para pembaca tidak membuang uang serta selalu memperhatikan alam di kota Madiun. Dalam pembuatan majalah digital "MADIUN MAGZ" ini merupakan karya awal penulis yang sejatinya memerlukan sebuah observasi langsung dan terjun langsung ditengah -tengah masyarakat kota Madiun secara langsung agar dapat mnegetahui apa saja dan bagaimana tanggapan orang mengenai majalah tersebut.[5] 
3. Penelitian yang dilakukan oleh Andi Nur Rachman dan Cecep Muhamad Sidik Ramdani, pada tahun 2016, penelitian ini yang berjudul "IbM PELATIHAN PEMANFAATAN E-COMMERCE SEBAGAI MEDIA PEMASARAN GLOBAL UNTUK PENINGKATAN PENJUALAN PRODUK KELOM GEULIS (Studi Kasus: UKM kelom geulis Tamansari Tasikmalaya)". Penelitian menjelaskan tentang Kegiatan pengabdian pada masyarakat adalah penguatan daya beli produk Kelom Geulis melalui implementasi E-Commerce berbasis Web dan pendampingan penggunaannya menggunakan teknologi informasi pada UKM pengrajin kelom geulis Regga dan Salwa di kecamatan Tamansari Tasikmalaya, sehingga meningkatkan kemandirian ekonomi melalui usaha kerajinan kelom geulis sebagai produk khas daerah Tasikmalaya, khususnya pada keterampilan pemanfaatan teknologi informasi dan internet dalam kegiatan marketing secara global. Permasalahan yang diangkat adalah peningkatan pelayanan penjualan, pemasaran, pemesanan produk dari konsumen dan peningkatan manajemen (organizer) pemesanan produk dengan implementasi teknologi informasi. Solusi yang ditawarkan adalah pembuatan aplikasi eCommerce dibuat berbasis teknologi web dan mobile web. Penerapan aplikasi kepada mitra melalui kegiatan transfer knowledge melalui pelatihan dan pendampingan mitra dalam menggunakan aplikasi e-commerce. Pelaksanaan kegiatan dengan metode Rational Unified Process (RUP) terdiri dari Inception, Elaboration, Construction dan terakhir transition. Detail dari fase RUP diantaranya Focus Group Discussion (FGD) untuk menjalin keterbukaan, kepercayaan, dan memahami persepsi, sikap, serta pengalaman dan persoalan yang dimiliki pengrajin (Salwa dan Regga Kelom Geulis) dalam melakukan pemasaran melalui internet, pembuatan aplikasi sesuai hasil FGD, kemudian dilanjutkan pada pendampingan yaitu penyuluhan dan pelatihan penggunaan E-Commerce sebagai yang meliputi desain iklan, perawatan domain, upload konten iklan di aplikasi E-Commerce, manajemen pemasaran, organizer pesanan pelanggan melalui eCommerce, hingga perawatan website. [6]

4. Penelitian yang dilakukan oleh Aloysius Bagas Pradipta Irianto, pada tahun 2015, penelitian ini yang berjudul "PEMANFAATAN SOCIAL MEDIA UNTUK MENINGKATKAN MARKET SHARE UKM". Penelitian ini menjelaskan tentang Globalisasi pasar telah mempengaruhi perilaku perdagangan yang selalu berusaha untuk memenuhi kebutuhan konsumen. Hal itu mempengaruhi Usaha Kecil Menengah (UKM) yang juga dituntut untuk dapat mengikuti perkembangan pasar agar dapat bertahan dan meningkatkan marketshare. Usaha Kecil Menengah (UKM) adalah kelompok usaha terbesar di Indonesia bahkan mungkin di Dunia. Pada tahun 2001, UKM memberikan andil 99\% dalam jumlah badan usaha dan 99,6\% dalam penyerapan tenaga kerja. Banyaknya UKM ini tentu disebabkan karena produk-produk dari UKM sangat diminati bahkan dibutuhkan oleh masyarakat. Namun demikian tidak semua produk-produk dari UKM dikenal luas oleh masyarakat. Hal ini disebabkan karena promosi yang dilakukan oleh UKM kalah gencar dengan promosi dari Industri yang lebih besar. Penyebab utama dari hal ini adalah minimnnya anggaran promosi dari UKM. Untuk itulah mengapa social media (WeChat) menjadi penting sebagai salah satu media promosi praktis, yang murah, handal dan dapat menjangkau seluruh pengguna.[7]

5. Penelitian Penelitian yang dilakukan oleh Deru R. Indika dan Cindy Jovita, pada tahun 2017, penelitian yang bejudul "MEDIA SOSIAL INSTAGRAM SEBAGAI SARANA PROMOSI UNTUK MENINGKATKAN MINAT BELI KONSUMEN". Penelitian ini mejelaskan tentang Kecepatan akses internet dan pesatnya pertumbuhan industri smartphone memudahkan orang untuk mendapatkan informasi. Di bidang marketing, hal ini memengaruhi bagaimana promosi dilakukan Penggunaan media sosial yang sebenarnya berarti untuk interaksi sosial antara individu online menjadi umum digunakan oleh perusahaan sebagai alat promosi termasuk di industri pariwisata. Salah satu Media sosial yang sering digunakan adalah Instagram, sebuah aplikasi yang memungkinkan penggunanya bagikan foto dan gambar bersama dengan pesan singkat dengan pengguna lain. Pelajaran ini membahas bagaimana Instagram sebagai media sosial dapat mempengaruhi niat membeli konsumen menuju tempat tujuan wisata. Subjek penelitian adalah Floating Market yang berlokasi di Jl Lembang, Bandung, Jawa Barat. Hasilnya menunjukkan informasi yang disampaikan melalui Instagram efektif dalam meningkatkan niat beli konsumen menjadi $50,2 \%$. [8] 
6. Penelitian yang dilakukan oleh Margaretha Linda Samantha, pada tahun 2016, penelitian ini yang berjudul "Kepuasan Pelanggan Dalam Membaca Majalah Surabaya City Guide". Penelitian ini mejelaskan tentang Majalah Surabaya City Guide (Majalah SCG) merupakan salah satu majalah free magazine yang ada di Surabaya. Walau menjadi majalah free, majalah ini dapat didapatkan dengan berlangganan dengan membayar ongkos kirim majalah. Lebih dari 500 pelanggan yang berlangganan Majalah SCG yang tersebar di area Surabaya dan sekitarnya. untuk penelitian ini, peneliti hanya meneliti pelanggan yang berada di wilayah kota Surabaya dengan jumlah responden 497 orang dari data terakhir februari 2016(Litbang Majalah SCG). Penelitian kepuasan ini menggunakan teori Uses an Gratifivatons, model dari PhilipPalmgreen yang mencari kepuasan melalui variabel motif (Gratification Sought : GS) dan variabel kepuasan (Gratification Obtained: GO). GO dan GS dicari menggunakan indikator Diversion, Personal Relationship, Personal Identity, dan Surveillance. Pelanggan dianggap puas jika nilai mean GS $<$ GO. Hasil penelitian ini menyebutkan bahwa kepuasan tertinggi didapatkan pada indikator Personal Relationship. Sedangkan kepuasan terendah pada indikator Diversion.[9]

7. Penelitian yang dilakukan oleh Aris Jatmika Diyatma, pada tahun 2017, penelitian ini yang berjudul "PENGARUH PROMOSI MELALUI MEDIA SOSIAL INSTAGRAM TERHADAP KEPUTUSAN PEMBELIAN PRODUK SAKA BISTRO \& BAR". Penelitian ini menjelaskan tentang Bandung sekarang ini terkenal dengan kota kuliner, dimana hampir di setiap sudut kota terdapat tempat makanan baik dari mulai warung pinggir jalan sampai ke berbagai jenis restoran, café, dan jenis tempat lainnya. Banyaknya restoran dan café sejenis memaksa Saka Bistro berinovasi dalam memasarkan produk makanannya. Meningkatnya jumlah pengguna media sosial Instagram di manfaatkan oleh Saka Bistro \& Bar sebagai media promosi yang paling diandalkan karena tidak memiliki batasan jumlah karakter tulisan, bisa memuat foto, mendunia, dan intinya seperti majalah berjalan saja. Tujuan dari penelitian ini adalah untuk mengetahui seberapa besar pengaruh penggunaan promosi melalui media sosial instagram terhadap keputusan pembelian konsumen pada produk Saka Bistro \& Bar. Jenis penelitian ini adalah penelitian deskriptif. Populasi dari penelitian ini adalah followers dari akun instagram @sakabistrobar. Pengambilan sampel menggunakan rumus dari Taro Yamane dengan jumlah sampel 99 followers. Analisis data yang digunakan adalah regresi linier sederhana, dengan hasil penelitian yaitu penggunaan promosi melalui media sosial instagram berpengaruh sebesar $83 \%$ bagi keputusan pembelian konsumen pada produk Saka Bistro \& Bar sedangkan sisanya dipengaruhi oleh faktor-faktor lain.[10]

\section{HASIL DAN PEMBAHASAN}

Majalah mini telah di buat menggunakan aplikasi pengolah grafis Adobe Illustrator CS3, gambar yang di buat berukuran rasio 1:1 atau 640x640 piksel, dibuat sampai 10 buah gambar, dan telah di masukkan di Instagram. Dari hasil penelitian yang di buat, masyarakat cukup menyukai melihat lihat suatu produk yang di pasarkan melalui sosial media Instagram yang di jadi satukan, karena serupa seperti membaca majalah atau koran cetak, sehingga semua informasi terkumpul jadi satu, karena memang cenderung lebih mudah dalam mencari dan melihatnya, dan lebih terjamin karena bekerja sama langsung dengan akun penjualnya. Orang orang yang ingin memasarkan produknya pun lebih mudah karena hanya perlu memberikan informasi produknya sebenar-benarnya, sehingga nantinya admin dari akun JOOSNEE MAGAZINE akan memilih produk mana yang akan dipromosikan, admin yang mengelola akun ini adalah Yunita dan Mutia, Mutia yang akan mendata produk produk yang masuk melalui pesan akun Instagramnya, mengumpulkan data dari produknya, lalu di diskusikan bersama apakah produk tersebut layak di promosikan atau tidak, dan Yunita yang akan mengedit datanya di Adobe Illustrator dan menguploadnya di Instagram.

Namun semua informasi tersebut masih memiliki kekurangan karena hanya dapat dilihat oleh orang yang mengetahui cara menggunakan instagram. Tetapi dengan jumlah pengguna Instagram yang semakin banyak dari tahun ke tahun, terakhir menurut data dari Instagram bahwa tanggal 26 April 2017 saja penggunanya sudah mencapai 700 juta sejak peluncurannya 6 Oktober 2010 lalu. Dan dengan adanya perbedaan yang di buat oleh akun tersebut dengan berbentuk seperti majalah hingga berbeda dari yang lain, akun tersebut pun mendapat perhatian dari beberapa masyarakat, seperti 
jumlah followers dan jumlah like yang meningkat sejak pertama kali peluncuran akun tersebut, itu berarti akun tersebut semakin di kenal banyak orang, itu berarti orang orang sudah terbantu dalam memasarkan produk dan mencari informasi mengenai produk produk penjualan yang terpercaya.

Untuk mencari informasi produk produk yang ada hanya dengan melihat akun tersebut, dengan cara menggunakan smartphone lalu nyalakan data seluler atau pun sambungkan ke wifi jika ada, lalu buka aplikasi Instagram di smartphone atau install terlebih dahulu aplikasi Instagram tersebut jika belum memiliki aplikasinya, jika sudah memliki aplikasinya lakukan login menggunakan akun milik pribadi dengan memasukkan username dan passwordnya, jika belum memiliki akunnya bisa daftar terlebih dahulu, lalu pergi ke bagian explore di Instagram dan ketik di kolom pencarian yang berada di paling atas lalu ketikkan nama akunnya yaitu JOOSNEE MAGAZINE, jika sudah keluar nama akunnya maka dan klik akun tersebut untuk membukanya. Cara melihatnya pun mudah, hanya perlu klik fotonya dan di geser ke kiri untuk melihat yang lainnya lagi. Namun jika hanya ingin melihat lihat dan tidak ingin memasukkan akun atau pun mendaftar untuk memiliki akun, bisa juga di buka melalui browser seperti google chrome, mozilla dan lain sebagainya di smartphone maupun pc, dan ketikkan alamat urlnya yaitu www.instagram.com/joosneemagazine.

Majalah mini ini dibuat dengan semenarik mungkin agar masyasrakat yang melihat merasa tertarik dan mudah dalam mengingat akunnya maupun produknya, tampilan yang sangat menarik dengan perpaduan warna yang elegan mampu membuat masyarakat masa kini merasa lebih senang melihatnya dibandingkan melihat informasi dari majalah biasa yang sudah monoton dan harus membelinya di toko, sedangkan majalah mini yang dibuat melalui media sosial Instagram, kita hanya harus membuka di gadget yang kita miliki.

Berikut adalah gambar yang telah di terapkan di media sosial Instagram dalam tampilan smartphone :

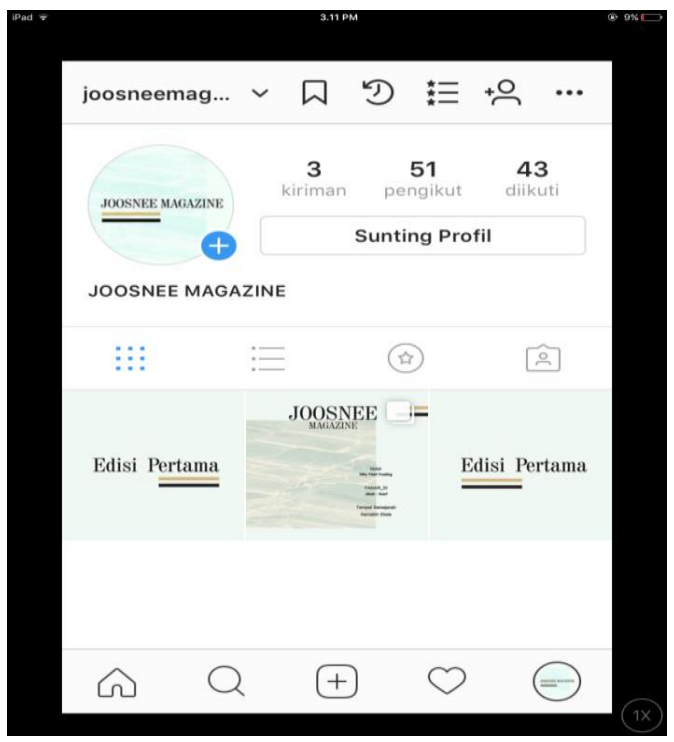

Gambar 1. Tampilan Profile Instagram JOOSNEE MAGAZINE

Gambar 1. merupakan Tampilan profil akun media sosial Instagram JOOSNEE MAGAZINE, dengan jumlah postingan 3, pumlah pengikut 51 , dan jumlah yang diikuti 43 , dengan gambar yang berada di sebelah kiri dengan judul "Edisi Pertama", gambar di tengah merupakan Foto Slide JOOSNEE MAGAZINE, gambar di berada di sebelah kanan dengan judul "Edisi Pertama". 


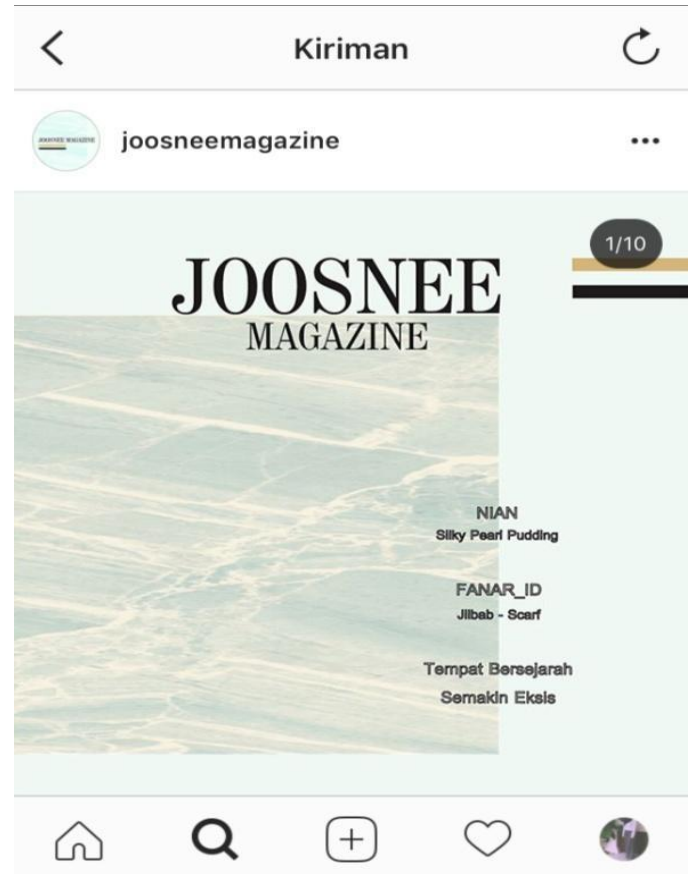

Gambar 2. Cover Majalah

Gambar 2. merupakan gambar Cover majalah Edisi Pertama, dengan judul JOOSNEE MAGAZINE dan tema yang di bahas ialah, NIAN - Silky Pearl Pudding, FANAR_ID - Jilbab, Scarfdan Tempat Bersejarah, dengan jumlah foto mancapai 10 Slide.

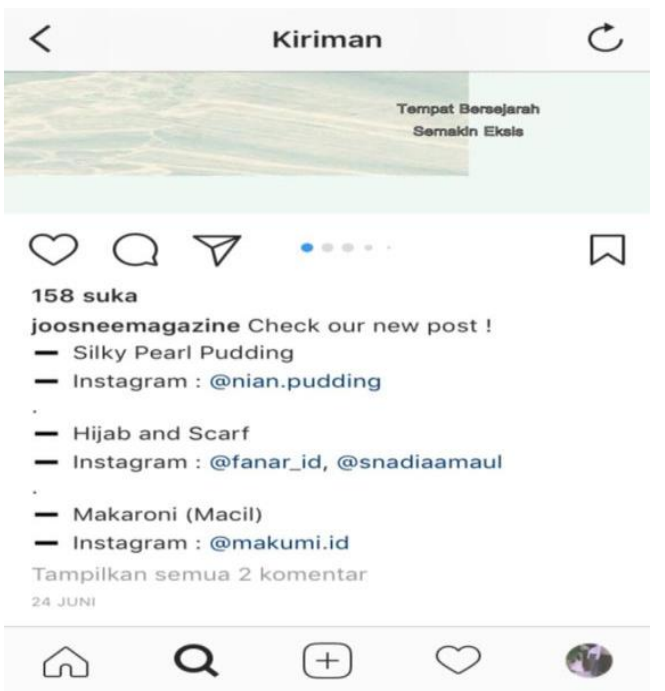

Gambar 3. Keterangan Posting

Gambar 3. merupakan keterangan dari gambar yang telah di unggah di Instagram JOOSNEE MAGAZINE. Dengan keterangan postingannya : Silky Pearl Pudding - Instagram : @ nian.pudding, Hijab dan Scarf - Instagram : @fanar_id @ snadiaamaul, Makaroni (Macil) Instagram : @makumi.id.

Berikut adalah gambar yang telah di buat visualisasi desain majalahnya : 


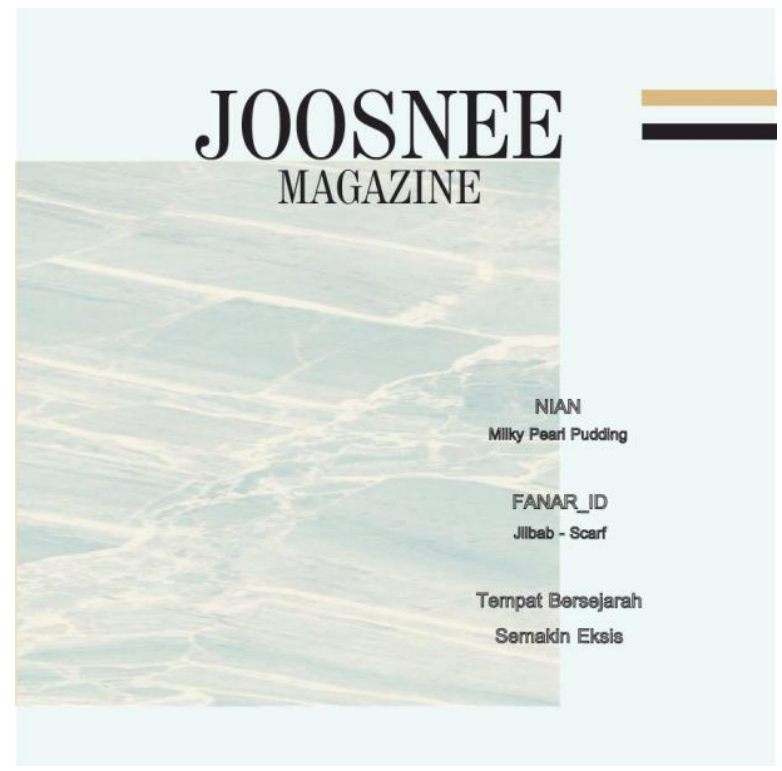

Gambar 4. Cover Majalah Online

Gambar 4. merupakan Cover dari desain majalah online yang di publikasikan pada media sosial Instagram dengan nama akun "JOOSNEE MAGAZINE" yang dapat di liat di semua platfom seperti android, iOS, dan di semua gadget seperti smartphone, tablet, bahkan laptop atau komputer.
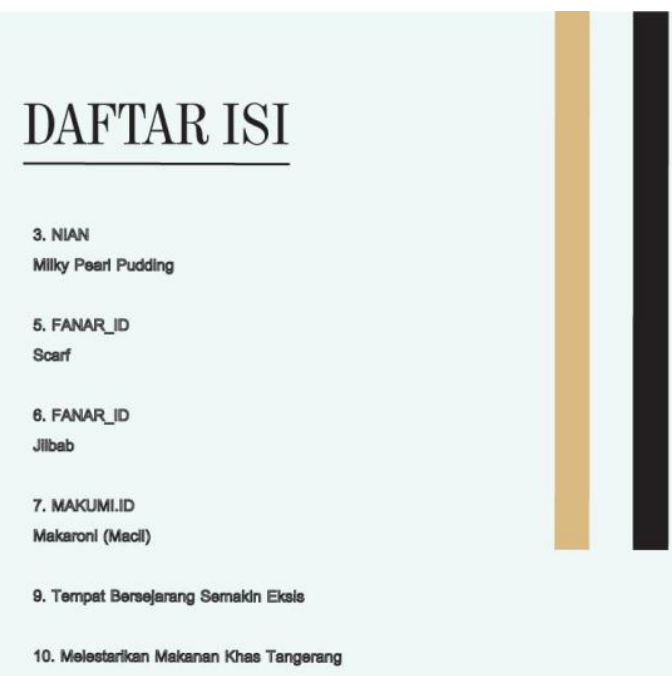

Gambar 5. Daftar ISI

Gambar 5. merupakan halaman kedua di majalah tersebut, setelah Cover Majalah yakni Daftar Isi majalah, yang memuat keterangan judul dari bahasan yang di muat di majalah tersebut dan ada di halaman berapa bahasan tersebut berada. 


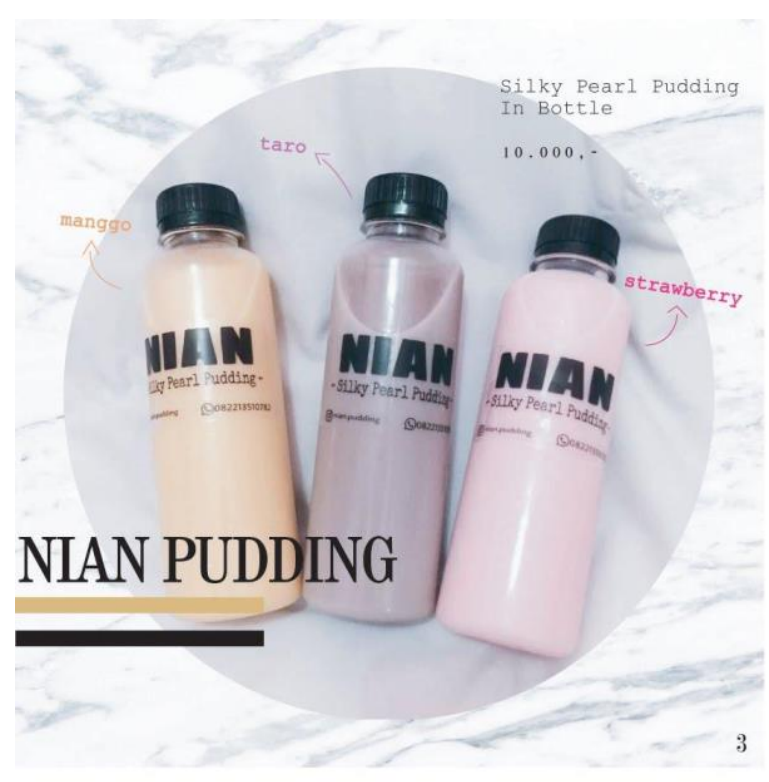

Gambar 6. Produk Minuman

Gambar 6. merupakan halaman ke 3 di majalah, di halaman ini terdapat produk yang di perkenalkan kepada masyarakat luas, dan produk yang di pasarkan ialah minuman dengan nama Silky Pearl Pudding In Bottle dengan rasa mango, taro, strawberry yang di produksi oleh Nian Pudding.

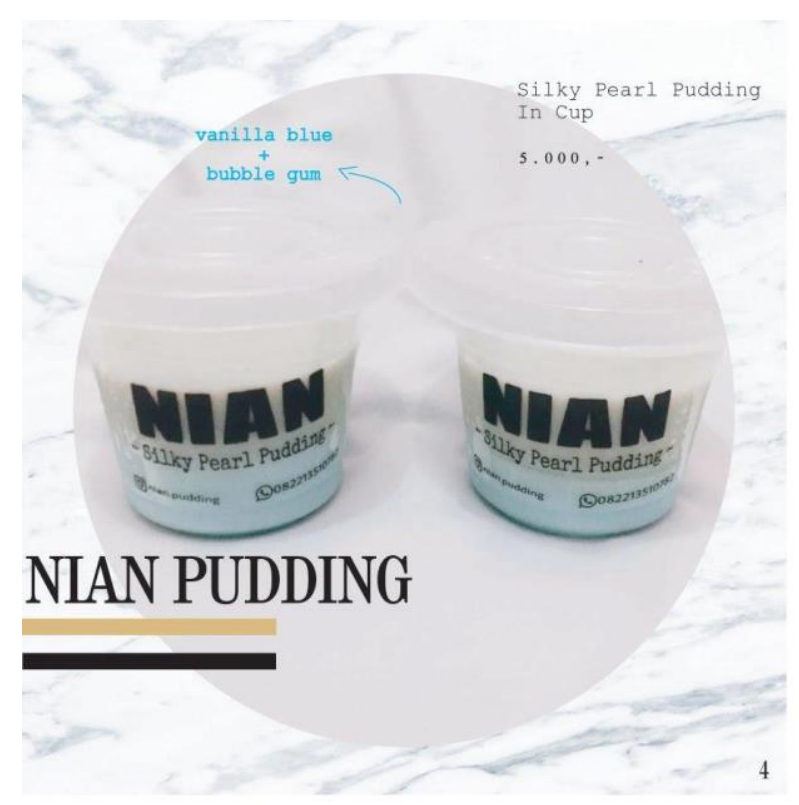

Gambar 7. Produk Makanan

Gambar 7. merupakan halaman ke 4 di majalah, di halaman ini terdapat produk yang di perkenalkan kepada masyarakat luas, dan produk yang di pasarkan ialah makanan dengan nama Silky Pearl Pudding InCup dengan rasa vanilla blue + bubble gun yang di produksi oleh Nian Pudding. 


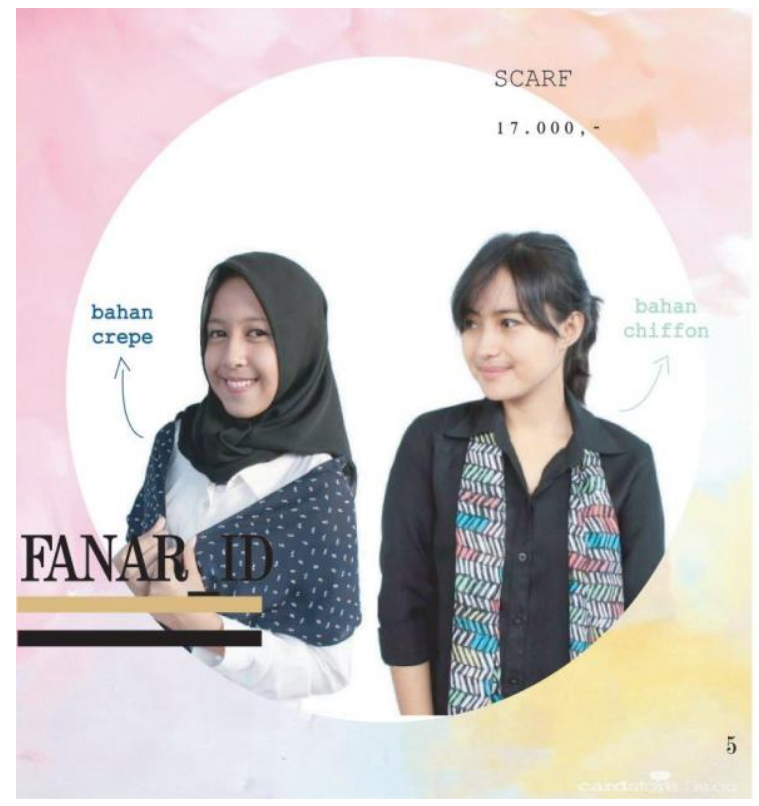

Gambar 8. Produk Khusus Wanita

Gambar 8. merupakan halaman ke 5 di majalah, di halaman ini terdapat produk yang di perkenalkan kepada masyarakat luas, dan produk yang di pasarkan ialah scarf dengan bahan crepe dan bahan chiffon, untuk para wanita yang di produksi oleh Fanar_ID.

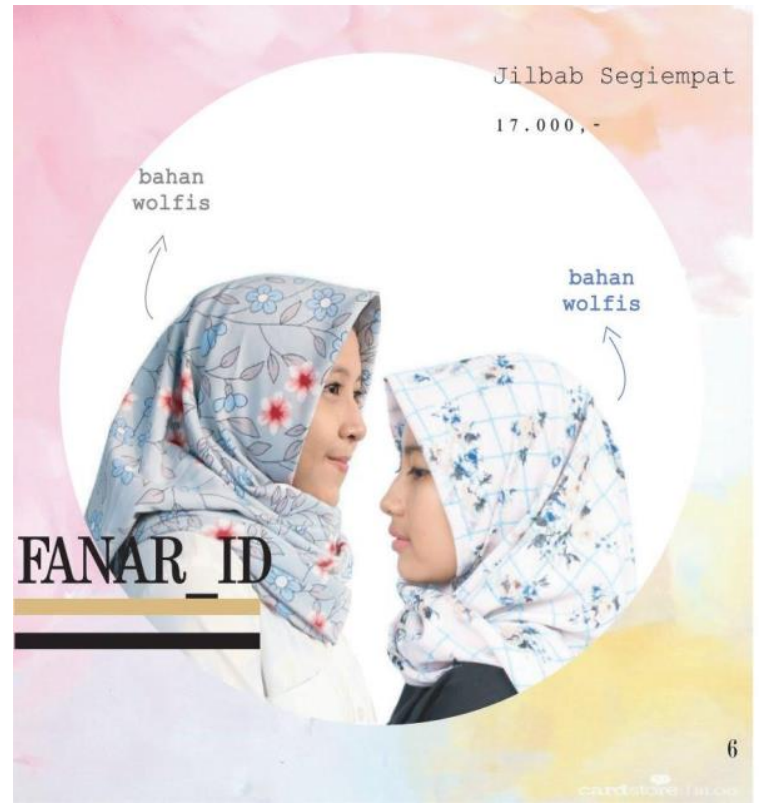

Gambar 9. Produk Jilbab

Gambar 9. merupakan halaman ke 6di majalah, di halaman ini terdapat produk yang di perkenalkan masyarakat luas, dan produk yang di pasarkan ialah Jilbab Segiempat dengan bahan Wolfis untuk para wanita yang di produksi oleh Fanar_ID. 


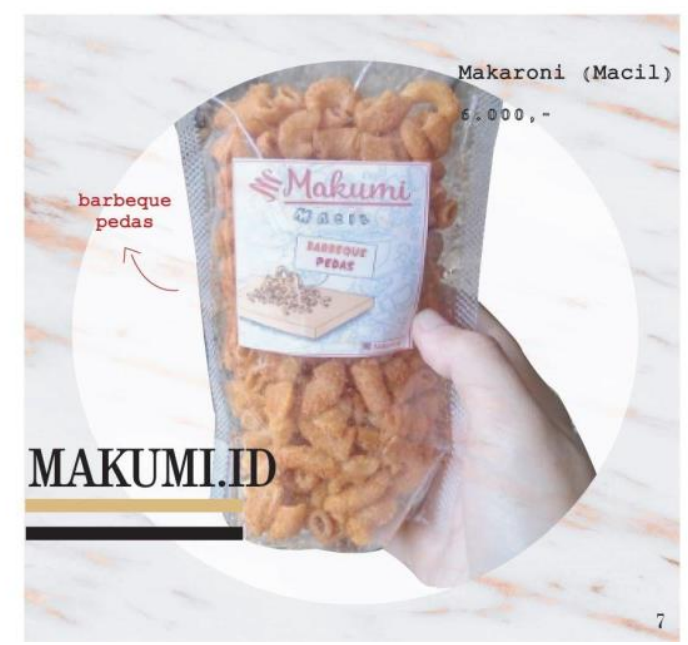

Gambar 10. Produk Makanan 1

Gambar 10. merupakan halaman ke $7 \mathrm{~d}$ i majalah, di halaman ini terdapat produk yang di perkenalkan masyarakat luas, dan produk yang di pasarkan ialah makaroni kering dengan rasa barbeque pedas yang di produksi oleh Makumi.ID.

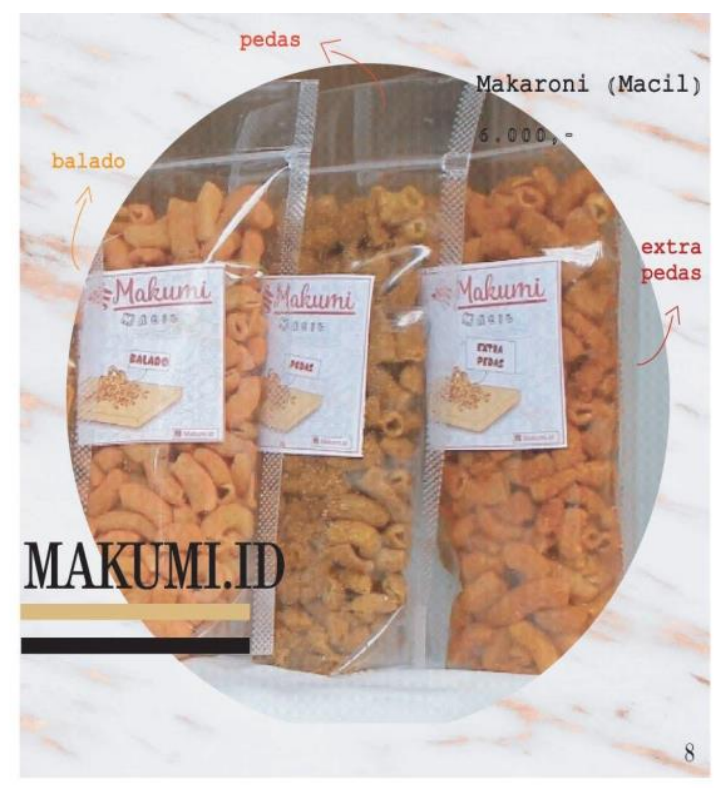

\section{Gambar 11. Produk Makanan 2}

Gambar 11. merupakan halaman ke 8 di majalah, di halaman ini terdapat produk yang di perkenalkan masyarakat luas, dan produk yang di pasarkan ialah makaroni kering dengan berbagai macam rasa seperti balado, pedas, dan ekstra pedas yang di produksi oleh Makumi.ID. 


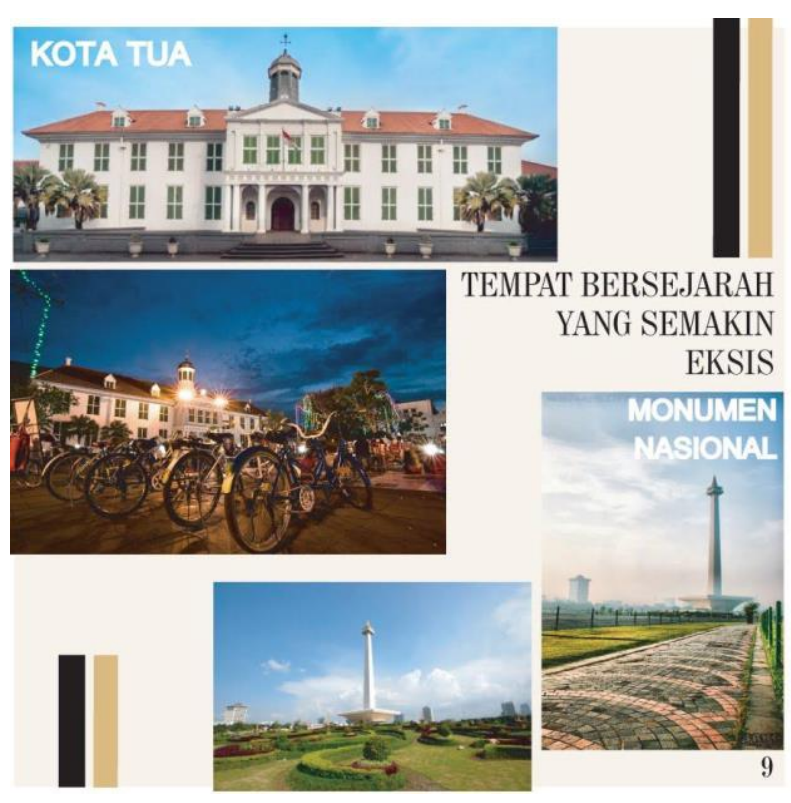

Gambar 12. Tempat Bersejarah

Gambar 12. merupakan halaman ke 9di majalah, di halaman ini terdapat informasi yang di perkenalkan kepada masyarakat luas dengan judul "Tempat Bersejarah Yang Semakin Eksis" yaitu di antaranya Kota Tua, dan Monumen Nasional.

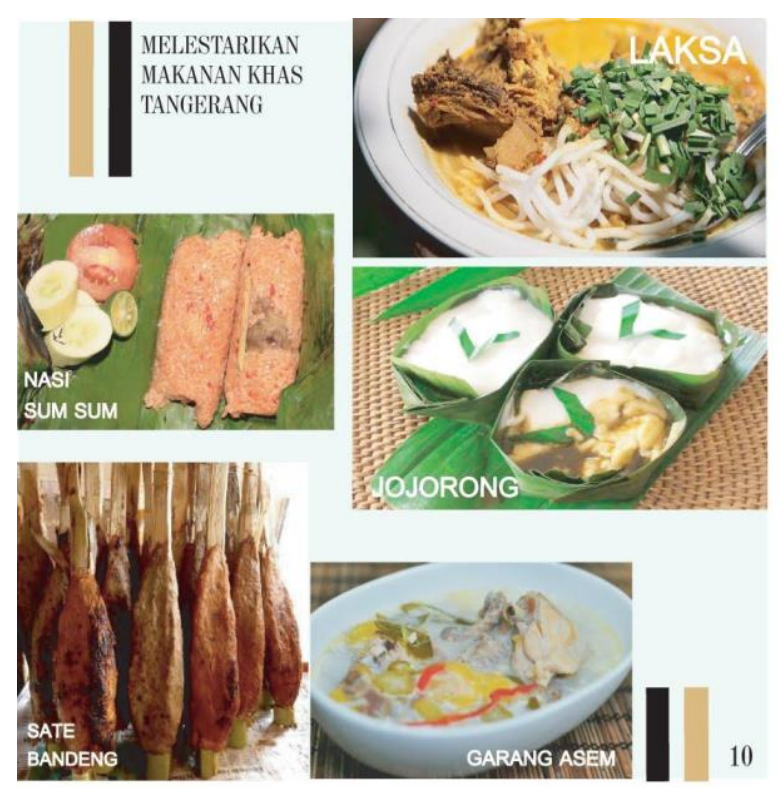

Gambar 13. Makanan Tradisional

Gambar 13. merupakan halaman ke 10 di majalah, di halaman ini terdapat informasi yang di perkenalkan kepada masyarakat luas dengan judul "Melestarikan Makanan Khas Tangerang" yaitu di antaranya Laksa, Nasi Sum Sum, Jojorong, Sate Bandeng, Garang Asem. 


\section{KESIMPULAN}

Dengan kemajuan teknologi yang ada sampai saat ini, dalam memasarkan mapun mencari informasi sebuah produk menjadi lebih mudah, yaitu menggunakan kemajuan teknologi informasiberbasis smartphone, tablet, maupun pc yang memiliki koneksi internet, melalui media sosial Instagram. Dan dengan di buatnya majalah mini dengantampilan yang baru dan berbeda dari yang lain yaitu dengan memanfaatkan fitur slide di Instagram, sehingga bisa memasukkan gambar maksimal hingga 10 gambar sehingga berbentuk seperti majalah mini. Dan juga lebih efisien sertalebih praktis dari segi penggunaan karena teknologi yang di gunakan sesuai dengan gaya hidup masyarakat yang serba praktis dalam mengakses informasi yang hanya perlu menggunakan smartphone atau tablet, atau pc dengan jaringan internet tanpa perlu membeli majalah atau koran cetak. Sehingga dengan telah di sesuaikannya menurut gaya hidup masyarakat yang ada, akan meningkat pula pola hidup masyarakat dengan nilai kesejahteraan khusus yang akhirnya membuat masyarakat Indonesia dan masyarakat dunia akan semakin meningkat.

\section{SARAN}

Dalam penelitian ini, penulis berharap agar pemasaran melalui media sosial instagram lebih kreatif lagi dari yang sebelum sebelumnya. Di dalam penelitian ini penulis masih belum bisa membuat masyarakat yang lebih luas lagi untuk melihat produk produk yang penulis pasarkan, sehingga masih harus bisa menarik minat masyarakat yang lebih lagi.

\section{DAFTARPUSTAKa}

1. Zebua, Manahati. 2016. Pemasaran Pariwisata : Menuju Festival Sail.Daerah Yogyakarta : Deepublish.

2. Desrianti, Dewi Immaniar. Sudaryono. Dwi Ayu Ningrum. 2014. Enriching Media Merchandise Sarana Penunjang Promosi Studi Kasus Pada Bookstore, Journal CCIT Vol. 7 No.3 - Mei 2014. Tangerang : Perguruan Tinggi Raharja.

3. Assegaf, H. Djafar. 2010. Jurnalistik Masa Kini. Jakarta : Ghalia Indonesia.

4. Sudarmaji, 2015, Rancangan bangun majalah kampus online berbasis web, Jurnal INFORMA Politeknik Indonusa Surakarta ISSN : 2442-7942 Vol. 1 Nomor 1 Tahun 2015, Politeknik Indonusa Surakarta.

5. Yudarnadi Firmansyah, Santoso Nicko Willy, 2015, Pembuatan majalah digital magazine sebagai media promosi wisata dan budaya karesidenan madiun dengan menggunakan software pengolahan grafis, Jurnal Ilmiah Teknologi dan Informasi Asia Vol. 9 No 1, Februari 2015, STMIK ASIA Malang.

6. Rachman Andi Nur, Cecep, 2016, IbM pelatihan pemanfaatan e-commerce sebagai media pemasaran global untuk peningkatan penjual produk kelom geulis(Studi Kasus: UKM kelom geulis Tamansari Tasikmalaya), Jurnal Siliwangi Vol. 2 No. 1 Mei 2016, Universitas Siliwangi.

7. Aloysius, 2015, Pemanfaatan sosial media untuk meningkatkan market share UKM ,Teknomatika Vol. 8, No. 1, Juli 2015, Universitas Atma Jaya Yogyakarta.

8. Deru , Jovita Cindy, 2017, Media sosial Instagram sebagai sarana promosi untuk meningkatkan minat beli konsumen, Jurnal Bisnis Terapan Volume 01, Nomor 01, Juni 2017, Universitas Padjadjaran, Bandung.

9. Samantha Linda Margaretha,2016, Kepuasan Pelanggan Dalam Membaca Majalah Surabaya City Guide, jurnal E-Komunikasi Vol 4. No.1 Tahun 2016, Universitas Kristen Petra Surabaya.

10. Diyatma Aris Jatmika, 2017, Pengaruh promosi melalui media sosial instagram terhadap keputusan pembelian produk saka bistro \& bar, e-Proceeding of Management : Vol.4, No.1 April 2017, Universitas Telkom. 